Web Jurnal:

http://ejournal.kemenperin.go.id/jli

\title{
Pengaruh penambahan Carboxyl Methyl Cellulose (CMC) dan asam sitrat terhadap mutu dan ketahanan simpan susu jagung
}

\section{Effect of Carboxyl Methyl Cellulose (CMC) and citric acid on quality and storage durability of corn milk}

Citra Setiawati*, Kamsina Kamsina, Inda Three Anova, Firdausni Firdausni, dan Yulia Helmi Diza

Balai Riset dan Standardisasi Industri Padang

Jl. Raya LIK No. 23 Ulu Gadut Padang 25164, Indonesia

* e-mail: citra.yep@gmail.com

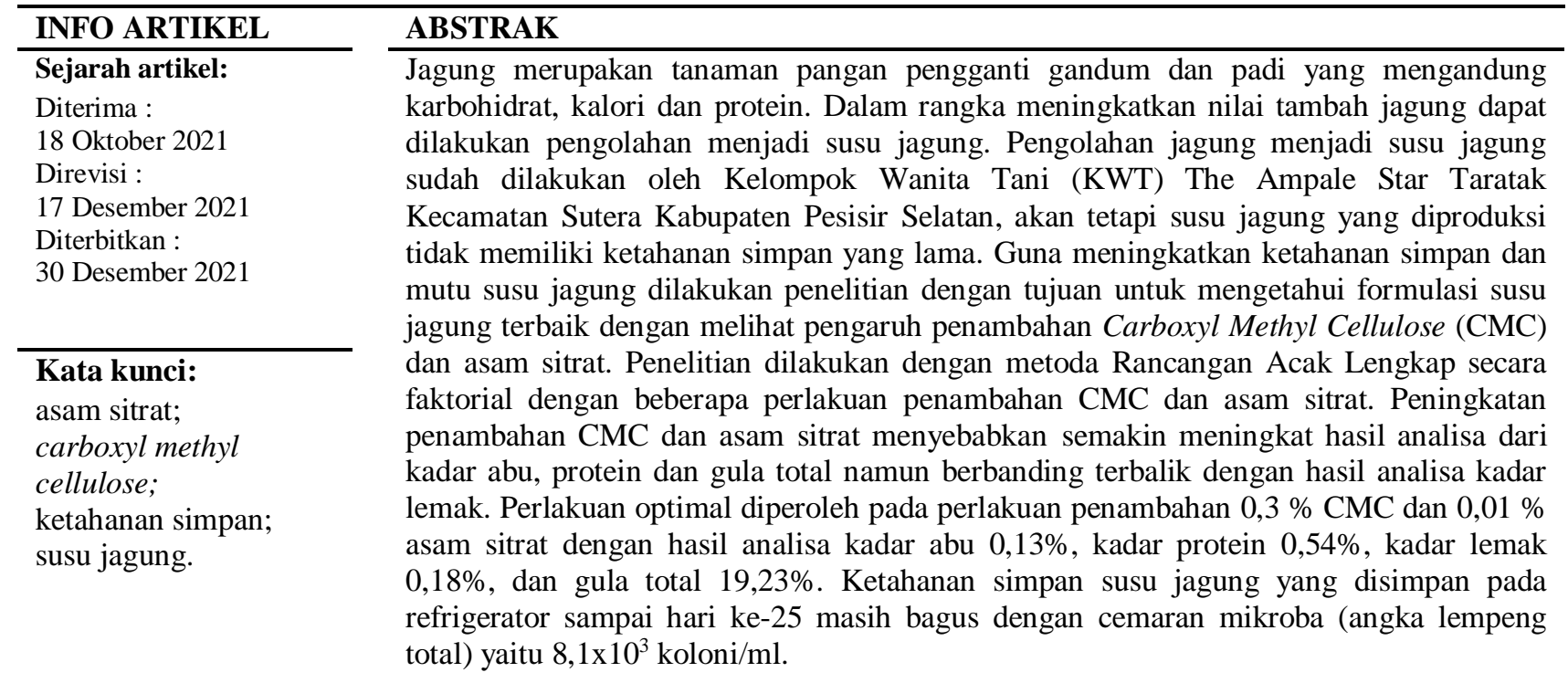

Keywords:
citric acid;
carboxyl methyl
cellulose;
storage durability;
corn milk.

\begin{abstract}
Corn is a substitute for wheat and rice which contains carbohydrates, calories and protein. In order to increase the added value of corn, it can be processed into corn milk. The processing of corn into corn milk has been carried out by Kelompok Wanita Tani (KWT) The Ampale Star Taratak Kecamatan Sutera Kabupaten Pesisir Selatan, However, corn milk produced does not have a long shelf life. In order to increase the for storage durability and quality of corn milk, a study was conducted with the aim of knowing the best formulation of corn milk by looking at the effect of adding Carboxyl Methyl Cellulose (CMC) and citric acid. The research was conducted using a Completely Randomized Design (CRD) method with a several additional treatments of CMC and citric acid. The increase in the addition of CMC and citric acid causes the analysis results of ash content, protein and total sugar to also increase and inversely related for fat content. Optimum result was obtained at 0,3\% CMC and 0,01\% asam sitrat with analysis of $0.13 \%$ ash content, $0.54 \%$ protein content, $0.18 \%$ fat content, $19.23 \%$ total sugar. Storage durability until the 25th day of microbial contamination (total plate number) that is $8.1 \times 103$ colonies $/ \mathrm{ml}$.
\end{abstract}




\section{Pendahuluan}

Perkembangan zaman mempengaruhi pola konsumsi masyarakat terhadap jenis bahan makanan dari berbahan hewani menjadi nabati. Pada umumnya, pengolahan bahan makanan nabati berasal dari komoditi kacangkacangan dan serelia. Beberapa komoditi kacangkacangan dan serelia digunakan sebagai bahan baku dalam pembuatan susu. Susu nabati yang umumnya ditemukan di pasaran yaitu susu kedelai. Namun seiring berkembangnya zaman, telah dikembangkan susu nabati dari bahan makanan nabati lainnya seperti jagung (Dharmawan et al., 2019) .

Jagung (Zea mays L.) merupakan salah satu tanaman pangan dunia yang komponen utamanya karbohidrat. Jagung mengandung kalori dan protein yang mirip dengan padi yang dapat tumbuh pada berbagai macam jenis tanah. Jagung diolah menjadi jagung pipil yang dikemas dalam kaleng, jagung pipil yang dibekukan dan aneka olahan lainnya, dimana dalam 100 gram jagung terkandung 73,7 gram karbohidrat, 9,2 gram protein, dan $11 \%$ sukrosa (Wardhani et al., 2015). Menurut (Sutini et al., 2020), kandungan karbohidrat pada jagung dapat mencapai $80 \%$ dari keseluruhan bahan kering biji.

Menurut data dari Badan Pusat Statistik, (2019), produksi jagung nasional pada tahun 2018 yaitu sebesar 30 juta ton. Dari total jumlah tersebut, sebesar 925.564 ton berasal dari Provinsi Sumatera Barat. Dalam rangka meningkatkan nilai tambah pada jagung dapat dilakukan pengolahan menjadi susu jagung. Pembuatan susu jagung diproses melalui penghancuran biji jagung yang sudah direbus dan disaring sehingga menghasilkan filtrat, lalu di pasteurisasi dan diberi flavor untuk meningkatkan rasanya (Muhajir et al., 2014).

Susu jagung dibutuhkan bagi seseorang yang tidak cocok mengkonsumsi susu sapi. Susu jagung mempunyai susunan asam amino yang mirip dengan susu sapi. Susu jagung merupakan salah satu minuman suplemen (tambahan) yang dapat menjaga kondisi tubuh agar tidak mudah terserang penyakit. Susu jagung dapat memberikan tambahan energi yang diperlukan bagi tubuh (Setiawati and Puspitojati, 2011).

Susu jagung sudah diproduksi oleh Kelompok Wanita Tani (KWT) The Ampale Star Taratak Kecamatan Sutera Kabupaten Pesisir Selatan. Namun produk susu jagung tersebut tidak memiliki ketahanan simpan yang lama, sehingga mudah rusak dan tidak dapat diproduksi massal. Oleh sebab itu perlu dilakukan penelitian dalam rangka peningkatan mutu dan ketahanan simpan dari produk tersebut, agar dapat memberikan nilai tambah dan dapat dipasarkan dengan mudah sehingga menjadi produk unggulan Kabupaten Pesisir Selatan.

Salah satu strategi untuk meningkatkan mutu dan ketahanan simpan produk susu jagung dengan pemberian bahan tambahan pangan (BTP). Bahan tambahan pangan (BTP) ditambahkan ke dalam pangan untuk mempengaruhi sifat atau bentuk bahan pangan. dan memperbaiki karakter pangan untuk meningkatkan kualitas dari produk pangan itu sendiri (Ferdiansyah, 2016).

Menurut Peraturan Menteri Kesehatan Republik Indonesia No. 722/Menkes/PER/IX/88, berdasarkan fungsinya BTP dapat dikelompokan menjadi 14 kelompok yaitu; antioksidan, antikempal, pengasam, penetral, enzim, pemanis buatan, pemutih danpematang, penambah gizi, pengawet, pengemulsi, pemantap dan pengental, pewarna sintetis dan alami, penyedap rasa dan aroma, sekuestran (Menteri Kesehatan RI, 1988).

Salah satu fungsi BTP adalah sebagai zat pengemulsi yang memudahkan dalam pembentukan emulsi dan meningkatkan stabilitas pangan. Beberapa jenis pengemulsi yaitu karbohidrat, protein, phospolipid, bahan sintetik dan bahan lainnya seperti bahan organik. Sedangkan zat penstabil berfungsi untuk menstabilkan emulsi. Jenis-jenis zat penstabil adalah gelatin, sodium alginat, agar-agar, pektin, karagenan dan Carboxyl Methyl Cellulose (CMC) (Satiarini, 2006). CMC bersifat biodegradable, tidak berbau, tidak berwarna, tidak beracun, berbentuk bubuk atau butiran yang larut dalam air, namun tidak larut dalam larutan organik, stabil pada $\mathrm{pH}$ 2-10 dan tidak memiliki reaksi dengan senyawa organik lainnya.

Pemakaian CMC dapat memberikan tekstur yang baik dalam industri makanan. Fungsi CMC adalah sebagai pengental, stabilisator, dan pembentuk gel. Sebagai pengemulsi, CMC digunakan untuk memperbaiki tekstur dari produk yang memiliki kadar yang tinggi. Sedangkan sebagai pengental, CMC mengikat air yang menyebabkan molekul-molekul air terperangkap dalam struktur gel yang dibentuk oleh CMC (Widiantoko, 2014). Fungsi pengatur keasaman pada makanan yaitu membuat makanan menjadi lebih asam, lebih basa, atau netral. Beberapa pengatur keasaman yang diizinkan untuk digunakan dalam makanan yaitu aluminium amonim/ kalium/ natrium sulfat, asam laktat, asam sitrat, kalium, dan natrium bikarbonat.

Penelitian-penelitian yang berkaitan dengan peningkatan mutu susu jagung telah banyak dilakukan, diantaranya oleh (Wardhani et al., 2015) yaitu tentang proses pembuatan susu jagung dengan melihat pengaruh rasio air dan jagung terhadap $\mathrm{pH}$, kadar asam laktat, gula total, lemak, protein dan viskositas. Muhajir et al., (2014) melakukan penelitian pengaruh lama perebusan terhadap karakteristik fisik dan kimia susu jagung. Dharmawan et al., (2019) melakukan penelitian untuk mengetahui formulasi terbaik Carboxyl Methyl Cellulose (CMC) dan santan berdasarkan sifat fisikokimia dan sensori susu nabati jagung. Prabandari, (2011) melakukan penelitian tentang pengaruh penambahan berbagai jenis bahan penstabil terhadap karakteristik fisikokimia dan organoleptic yoghurt jagung. Harianja et al., (2015) meneliti pembuatan susu jagung dengan pengayaan kacang hijau bergerminasi dan penambahan CMC sebagai bahan penstabil.

Berdasarkan permasalahan-permasalahan dan penelitian yang telah dilakukan, maka dilakukan penelitian dengan tujuan untuk mengetahui formulasi susu jagung terbaik dengan melihat pengaruh 
penambahan Carboxyl Methyl Cellulose (CMC) dan asam sitrat dalam peningkatan mutu susu jagung.

\section{Metode}

\subsection{Bahan dan peralatan}

Bahan utama yang diperlukan adalah jagung yang berasal dari daerah Pesisir Selatan, gula pasir, asam sitrat, akuades, CMC dan garam halus. Peralatan yang digunakan blender, botol kemasan, tanur listrik, neraca analitik, labu kjeldhal $100 \mathrm{ml}$, peralatan penyulingan, pemanas listrik, soxhlet dan oven.

Penelitian menggunakan metoda Rancangan Acak Lengkap secara faktorial dengan perlakuan penambahan CMC dan asam sitrat. Variasi perlakuan tercantum pada Tabel 1.

Tabel 1.

Formulasi penambahan CMC dan asam sitrat

\begin{tabular}{lll}
\hline \multirow{2}{*}{ Perlakuan } & \multicolumn{2}{c}{ Penambahan } \\
\cline { 2 - 3 } A1B1 (kontrol) & CMC & Asam sitrat \\
A2B1 & $0 \%$ & $0 \%$ \\
A3B1 & $0,1 \%$ & $0 \%$ \\
A4B1 & $0,2 \%$ & $0 \%$ \\
A1B2 & $0,3 \%$ & $0 \%$ \\
A2B2 & $0 \%$ & $0,01 \%$ \\
A3B2 & $0,1 \%$ & $0,01 \%$ \\
A4B2 & $0,2 \%$ & $0,01 \%$ \\
A1B3 & $0,3 \%$ & $0,01 \%$ \\
A2B3 & $0 \%$ & $0,02 \%$ \\
A3B3 & $0,1 \%$ & $0,02 \%$ \\
A4B3 & $0,2 \%$ & $0,02 \%$ \\
\hline
\end{tabular}

\subsection{Pelaksanaan penelitian}

Pembuatan susu jagung diawali dengan jagung dikupas lalu dipipil. Selanjutnya sebanyak 200 gram pipilan jagung dihaluskan menggunakan blender dengan penambahan $800 \mathrm{ml}$ air, lalu disaring menggunakan kain saring. Hasil saringan tersebut dimasukan ke dalam panci stainless steel dan ditambahkan dengan gula pasir $10 \%$, CMC dan asam sitrat (sesuai dengan masingmasing perlakuan). Kemudian dipanaskan selama 15 menit pada suhu $80^{\circ} \mathrm{C}$. Setelah itu susu jagung didinginkan dan dimasukan ke dalam kemasan botol yang telah dipasteurisasi. Susu jagung yang telah dikemas, disimpan dalam lemari pendingin pada suhu $4^{\circ} \mathrm{C}$.

\subsection{Analisis dan pengolahan data}

Susu jagung dianalisis secara kimia meliputi kadar protein dengan metode Kjeldahl, total lemak dengan metode sokletasi, gula total dengan metode luff schoorl, kadar abu dengan metode gravimetri.

Uji ketahanan simpan dilakukan secara mikrobiologi terhadap cemaran mikroba berupa Angka Lempeng
Total sampai 25 hari (hari ke 0, 14 dan 25) sesuai dengan SNI 01-2891-1992 tentang Tata Cara Uji Makanan dan Minuman.

Data dari hasil pengujian dianalisis menggunakan analisa ragam (ANOVA) dengan selang kepercayaan 5\% dan uji beda nyata Duncan Multiple Range Test (DMRT).

\section{Hasil dan pembahasan}

\subsection{Analisis kimia bahan baku}

Analisis terhadap bahan baku pembuatan susu jagung diperoleh hasil karbohidrat (pati) sebesar 11,22\%, protein $2,65 \%$, serat kasar $0,57 \%$, lemak $0,84 \%$, gula total 3,39\% dan kalori sebesar 76,72 kkal.

\subsection{Analisis produk}

\subsubsection{Kadar abu}

Hasil analisis kadar abu disajikan pada Gambar 1. Berdasarkan hasil analisis variansi yang dilakukan, penambahan CMC dan asam sitrat saling berinteraksi satu sama lain dan berpengaruh nyata terhadap hasil analisis kadar abu yang diperoleh. Hal ini tunjukan dengan hasil Anova yang diperoleh yaitu F $(119,42)>$ Fcrit $(3,978)$. Kadar abu mengalami peningkatan seiring dengan kenaikan konsentrasi CMC dan asam sitrat yang ditambahkan.

Hal ini sejalan dengan hasil penelitian Hartatik and Damat, (2017) yang membuktikan penambahan bahan penstabil CMC dapat memberikan nilai kadar abu tertinggi dibandingkan dengan penambahan bahan penstabil gum Arab. Kadar abu yang dihasilkan dapat bernilai tinggi jika bahan pangan tersebut mengandung mineral yang tinggi (Pratiwi and Zaini, 2016).

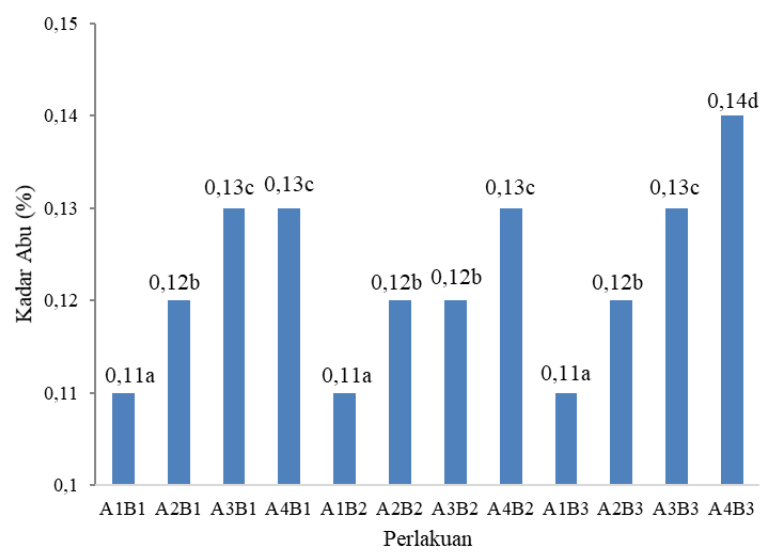

Gambar 1.Hasil analisa kadar abu pada susu jagung Keterangan : Nilai diikuti oleh huruf kecil yang sama berbeda tidak nyata (Uji Duncan $\alpha=5 \%$ )

Kadar abu terendah yaitu diperoleh pada perlakuan A1B1 $(0,11 \%)$ dan tidak berbeda dengan perlakuan A1B2 dan A1B3. Sedangkan Kadar abu tertinggi diperoleh pada perlakuan A4B3 yaitu sebesar 0,14\% yang berbeda nyata dengan hasil kadar abu perlakuan lainnya.

Abu merupakan zat organik sisa hasil pembakaran. Semua bahan organik akan terbakar sempurna menjadi 
air dan $\mathrm{CO}_{2}$ serta $\mathrm{NH}_{3}$. Kadar abu dalam bahan pangan merupakan mineral yang terdapat dalam suatu bahan (Sundari et al., 2015). Nilai kadar abu dalam pangan dipengaruhi oleh spesies, unsur hara tanah, iklim, lokasi berkembang dan perlakuan penanaman. Selain itu kadar abu terdiri dari unsur mineral, dimana pada saat proses pembakaran suhu $600^{\circ} \mathrm{C}$ bahan lain selain mineral akan terbakar dan menguap dan menyisakan zat anorganik (Agustina and Andriana, 2010; Muhajir et al., 2014).

\subsubsection{Protein}

Penambahan konsentrasi CMC dan asam sitrat berpengaruh nyata terhadap nilai protein pada susu jagung sesuai dengan hasil uji statistika (analisis variansi) yaitu diperoleh $\mathrm{F}(107,63)>$ Fcrit $(3,978)$. Penambahan kedua bahan tambahan tersebut menunjukan ada interaksi. Hasil analisa terhadap kadar protein pada susu jagung, semakin tinggi konsentrasi CMC dan asam sitrat yang ditambahkan maka semakin meningkat nilai kadar protein pada susu jagung (Gambar 2). Hasil tersebut disebabkan karena CMC dapat mengikat protein susu jagung bergerminasi sehingga pada proses pemasakan protein dapat dipertahankan.

Hasil ini sesuai dengan penelitian Harianja et al., (2015). Menurut Hartatik and Damat, (2017) penambahan penstabil konsentrasi CMC memiliki kelebihan yang dapat mencegah pengendapan protein dan berfungsi untuk mencegah terjadinya retrogradasi dan pengendapan pada titik isoelektriknya. Hal ini disebabkan oleh bergabungnya gugus karboksil dari CMC dengan muatan gugus positif dari protein. Sejalan dengan hasil penelitian Sari et al., (2014), penambahan asam sitrat pada keju mozarella dapat meningkatkan kadar protein.

Hasil uji beda nyata DMRT memperlihatkan kadar protein tertinggi yaitu diperoleh pada perlakuan A4B2 $(0,53 \%)$ yang berbeda nyata dengan perlakuan lainnya. Sedangkan kadar protein terendah diperoleh pada perlakuan A1B3 $(0,40 \%)$ yang juga berbeda nyata dengan perlakuan lainnya.

Berdasarkan hasil analisis yang dilakukan, kandungan protein yang diperoleh pada perlakuan A1B1 $(0,42 \%)$ mengalami penurunan dari kadar protein bahan baku jagung yaitu 2,65\%. Hal ini diduga disebabkan pemanasan pada suhu $100^{\circ} \mathrm{C}$ dan adanya penambahan air dalam proses pembuatan susu jagung. Menurut Muhajir et al., (2014), karena proses perebusan, protein yang terkandung dalam bahan makanan mengalami kerusakan karena panas.

Penentuan apakah suatu produk pangan memenuhi syarat untuk dikonsumsi adalah dengan mempertimbangkan persyaratan mutu yang telah ditetapkan dalam SNI. Produk susu jagung belum memiliki standar mutu (SNI) sehingga pada penelitian ini mengacu pada standar mutu susu kedelai.

Berdasarkan SNI 01-3830-1995 tentang susu kedelai, persyaratan kadar protein minimum adalah 2,0\%. Pada hasil penelitian yang dilakukan, kadar protein pada seluruh perlakuan belum memenuhi persyaratan mutu susu kedelai. Penyebabnya adalah kadar protein pada bahan baku jagung relatif rendah dibanding kadar protein pada kedelai. Kedelai mengandung protein sebesar $35-43 \%$, tergantung pada varietasnya. Kedelai mempunyai kandungan protein yang lebih tinggi dibanding dengan beras, jagung, tepung singkong, kacang hijau, daging, ikan segar dan telur ayam (Setiawati and Puspitojati, 2011). Perbedaan yang signifikan terhadap kandungan protein antara kedua produk ini, maka persyaratan analisis protein belum dapat dikategorikan.

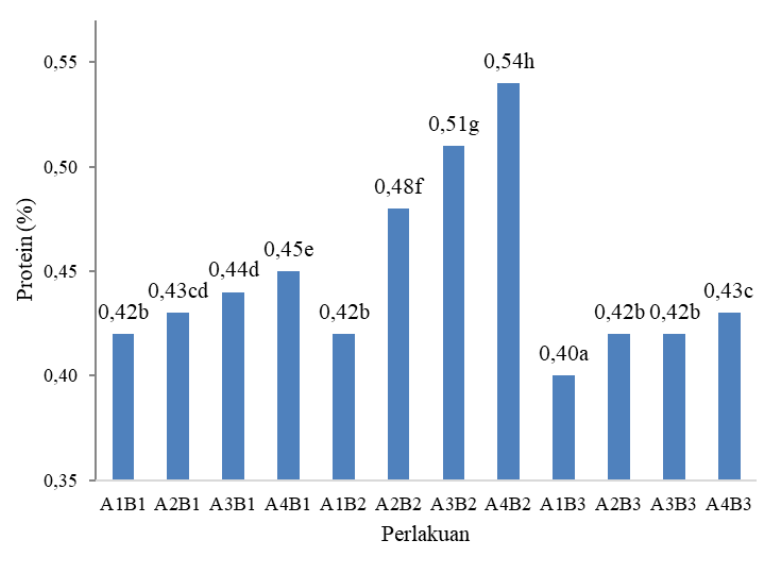

Gambar 2.Hasil analisa kadar protein pada susu jagung Keterangan : Nilai diikuti oleh huruf kecil yang sama berbeda tidak nyata (Uji Duncan $\alpha=5 \%$ )

\subsubsection{Total lemak}

Hasil analisis bahan baku yang digunakan pada penelitian ini diperoleh kandungan lemak sebesar 0,84\%. Setelah dilakukan pengolahan jagung menjadi susu jagung, diperoleh hasil total lemak sebesar 0,27\% (A1B1). Penurunan kadar lemak terjadi karena proses perebusan bahan baku menjadi susu jagung yang menyebabkan kerusakan pada lemak. Menurut Sundari et al., (2015), berdasarkan berat kering per 100 gr bahan pangan yang diolah melalui perebusan akan mengalami penurunan kadar lemak.

Setelah proses pengolahan, terjadi kerusakan lemak yang tergantung pada suhu yang digunakan serta waktu proses perebusan. Semakin tinggi suhu perebusan, maka semakin tinggi kerusakan lemak yang terjadi. Kerusakan lemak terjadi karena sifat lemak yang tidak tahan panas selama proses pemasakan, dimana lemak dapat menguap menjadi komponen lain. Kadar lemak merupakan jumlah lemak yang terkandung dalam bahan pangan. Lemak adalah senyawa organik yang terdapat hampir pada semua bahan pangan yang berfungsi sebagai penghantar panas, penambah kalori, serta dapat memperbaiki tekstur dan cita rasa dari bahan pangan (Sumarni et al., 2017).

Penambahan konsentrasi CMC dan asam sitrat pada susu jagung berpengaruh nyata terhadap hasil analisa kadar lemak pada susu dan saling berinteraksi, sesuai dengan hasil uji statistik yaitu analisis varians menyatakan nilai F $(115,52)>$ Fcrit $(3,978)$. Hasil analisis kadar lemak yang terkandung dalam susu jagung disajikan pada Gambar 3. Semakin tinggi kadar konsentrasi CMC dan Asam Sitrat maka semakin rendah nilai kadar lemak yang terkandung dalam susu jagung.

Penurunan kadar lemak dipengaruhi oleh peningkatan konsentrasi CMC sebagai bahan penstabil 
yang menyebabkan terjadinya efek dilusi. Dilusi merupakan penambahan zat tertentu ke dalam suatu bahan yang dapat menyebabkan penurunan kandungan nutrisi pada bahan tersebut. Tingkat dilusi yang terjadi tergantung dengan jenis bahan penstabil yang digunakan (Sumarni et al., 2017). Bahan penstabil CMC mempunyai sifat hidrofilik yang lebih mengikat air dibandingkan mengikat lemak. CMC tidak dapat larut dalam lemak, namun dapat berikatan dengan protein (Abdullah and Mutia, 2020).

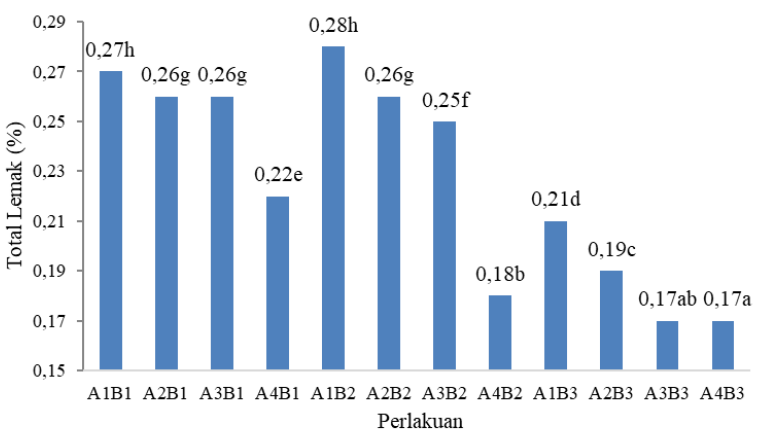

Gambar 3.Hasil analisa total lemak pada susu jagung Keterangan : Nilai diikuti oleh huruf kecil yang sama tidak berbeda nyata (Uji Duncan $\alpha=5 \%$ ).

Menurut penelitian Usmiati et al., (2020), kadar lemak pada susu sapi dipengaruhi oleh suhu yang digunakan pada proses pengolaham dan konsentrasi asam sitrat yang ditambahkan. Penggunaan konsentrasi asam sitrat 0,16-0,20\% menghasilkan kadar lemak mozarella susu sapi sekitar 10,013-13,121\%, sedangkan penambahan asam sitrat $0,13 \%$ menghasilkan kadar lemak keju sebesar 5,267\%. Sejalan dengan penelitian ini penambahan konsentrasi asam sitrat berkisar antara 0,01-0,02\%. Penambahan sedikit asam sitrat tidak terlalu mempengaruhi kenaikan nilai kadar lemak.

Kadar lemak tertinggi pada penelitian yang dilakukan yaitu pada perlakuan A1B2 $(0,28 \%)$ dan berbeda tidak nyata dengan perlakuan A1B1 $(0,273 \%)$. Sedangkan kadar lemak terendah diperoleh pada perlakuan A4B3 $(0,170 \%)$ dan berbeda tidak nyata dengan perlakuan A3B3 $(0,173 \%)$ dan A4B2 $(0,18 \%)$. Kadar total lemak dalam susu jagung untuk semua perlakuan belum memenuhi persyaratan mutu sesuai dengan SNI Susu Kedelai (SNI 01-3830-1995), karena kandungan lemak pada biji jagung lebih rendah dari pada kandungan lemak kedelai yang merupakan bahan dasar pembuatan susu kedelai. Kandungan lemak pada kedelai adalah 19,63\% (Setiawati and Puspitojati, 2011).

\subsubsection{Gula total}

Hasil analisa yang dilakukan pada produk susu jagung, diperoleh nilai gula total yaitu 14,78 \% (A1B1). Sedangkan kadar gula total pada bahan baku yaitu sebesar 3,39 \%. Kenaikan gula total pada produk susu jagung disebabkan karena adanya penambahan gula pasir pada saat proses pembuatan susu jagung.

Berdasarkan hasil uji statistik ANOVA, penambahan konsentrasi CMC dan asam sitrat pada susu jagung berpengaruh nyata terhadap hasil kadar gula total dengan nilai F $(232,09)>$ Fcrit $(3,978)$. Penambahan CMC dan asam sitrat juga saling berinteraksi. Hasil analisis sidik ragam ditunjukan pada Gambar 4, yang menyatakan bahwa rata-rata semua perlakuan berpengaruh nyata terhadap kadar gula total yang terkandung dalam susu jagung. Semakin tinggi kadar konsentrasi CMC dan asam sitrat yang ditambahkan maka semakin tinggi nilai kadar gula total yang terkandung dalam susu jagung.

Peningkatan kadar gula total dipengaruhi oleh konsentrasi CMC yang ditambahkan, sehingga kadar gula yang terukur semakin tinggi karena selulosa yang merupakan homopolisakarida linier yang berbobot molekular tinggi dengan satuan pengulang selobiaosa. CMC berperan sebagai penstabil, pengikat air maupun senyawa lain seperti gula (sukrosa) (Mailoa et al., 2017). Demikian juga bila semakin tinggi konsentrasi asam sitrat yang ditambahkan akan meningkatkan kadar gula total pada susu jagung. Kenaikan kadar gula disebabkan oleh semakin banyak sukrosa yang terhidrolisis menjadi gula reduksi. Menurut Trissanthi and Susanto, (2016), penambahan asam sitrat adalah untuk menambah rasa asam, modifikasi gula, sebagai pengawet serta dapat menginversi gula dalam minuman.

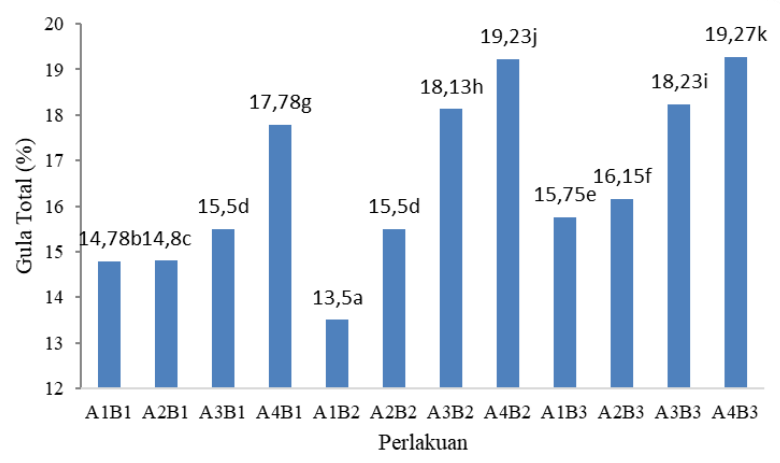

Gambar 4.Hasil analisa gula total pada susu jagung Keterangan : Nilai diikuti oleh huruf kecil yang sama tidak berbeda nyata (Uji Duncan $\alpha=5 \%$ )

Hasil analisa kadar gula total tertinggi yaitu pada perlakuan A4B3 (19,27\%) yang berdasarkan uji Duncan berbeda nyata dengan perlakuan lainnya. Sedangkan kadar gula total terendah yaitu pada perlakuan A1B2 $(13,50 \%)$ yang juga berbeda nyata dengan perlakuan lainnya.

\subsubsection{Ketahanan simpan}

Ketahanan simpan susu jagung diuji dengan melakukan uji mikrobiologi menggunakan metode total plate count (TPC) yang hanya menghitung jumlah koloni mikroba/bakteri tanpa melihat jenis dari mikroba pada produk tersebut. Angka Lempeng Total merupakan suatu metode kuantitatif untuk mengetahui jumlah mikroba secara keseluruhan, yang menggambarkan distribusi dan kualitas mikroba pada bahan pangan (Kamsina et al., 2020). Kandungan total bakteri (ALT) selama proses penyimpanan pada refrigerator mengalami peningkatan mulai dari pengamatan hari ke-0, ke-4 sampai hari ke-25 meskipun disimpan pada lemari pendingin (Gambar 5). 
Hasil uji statistik anova menyatakan bahwa penambahan konsentrasi CMC dan asam sitrat berpengaruh nyata terhadap daya simpan susu jagung dengan nilai $F(11,112)>$ Fcrit $(3,978)$. Nilai bakteri terendah yang terdapat pada susu jagung setelah disimpan selama 25 hari yaitu pada perlakuan A1B3 yaitu $8.100 \mathrm{koloni} / \mathrm{ml}$ berdasarkan hasil uji duncan tidak berbeda nyata dengan perlakuan A2B3, A4B2, A3B2, A3B3 dan A4B3 seperti yang dijelaskan pada Gambar 5. Sedangkan nilai ALT tertinggi pada hari ke-25 yaitu pada perlakuan A3B1 yaitu $470.000 \mathrm{koloni} / \mathrm{ml}$ yang berbeda sangat nyata dengan perlakuan lainnya.

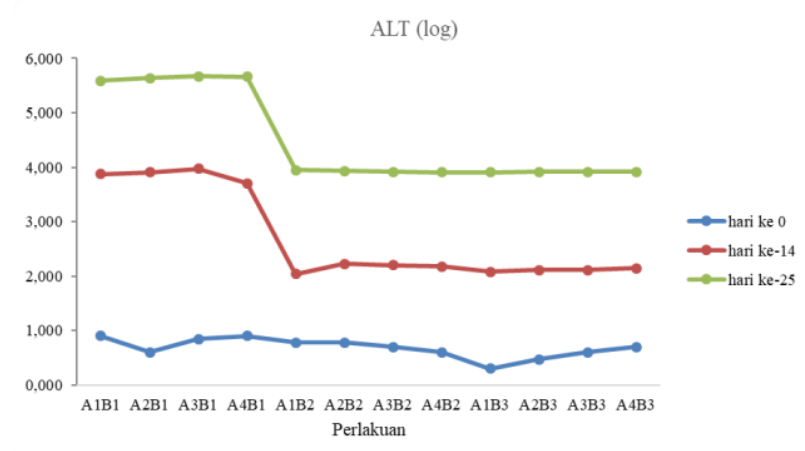

Gambar 5. Hasil analisa ALT pada susu jagung

Berdasarkan hasil tersebut semakin banyak penambahan konsentrasi asam sitrat, maka semakin lama daya simpan susu jagung. Menurut penelitian Berlian et al., (2016), proses pengawetan dapat dilakukan dengan menggunakan asam sitrat yang berfungsi sebagai antibakteri yang dapat menghambat pertumbuhan bakteri dan bertindak sebagai bahan pengawet.

Produk susu jagung yang disimpan pada suhu kamar memiliki ketahanan simpan sampai 3 (tiga) hari karena pertumbuhan mikroba sangat pesat untuk kedua jenis kemasan. Mikroba penyebab kerusakan bahan pangan seperti bakteri, kapang, dan khamir menyukai keadaan hangat dan lembab. Suhu optimum untuk pertumbuhan bakteri berbeda-beda, namun kapang dan khamir adalah $25-30^{\circ} \mathrm{C}$. Sedangkan pada penyimpanan suhu dingin pertumbuhan mikroba terhambat. Wasetiawan, 2009 dalam (Adji, 2010) menyatakan mikroba yang berkembang pada suhu ini adalah mikroba dari kelompok psikrofilik yang dapat tumbuh pada suhu 0$30^{\circ} \mathrm{C}$ dan memiliki suhu optimum pertumbuhan $15^{\circ} \mathrm{C}$.

Semakin lama penyimpanan yang dilakukan akan terjadi pertumbuhan mikroorganisme diantaranya adalah akibat aktivitas air yang tinggi pada susu jagung. Pertumbuhan bakteri dipengaruhi oleh $\mathrm{pH}$, air, oksidasi reduksi, kandungan nutrisi, bahan antimikroba, struktur bahan makanan, suhu penyimpanan, kelembaban, tekanan gas $\left(\mathrm{O}_{2}\right)$, cahaya dan pengaruh sinar ultraviolet. Kontaminasi mikroba diduga disebabkan adanya cemaran mikroba pada peralatan yang digunakan. Walaupun peralatan yang digunakan telah dibersihkan, akan tetapi tetap kontak dengan udara, sehingga apabila mikroba yang ada di udara menempel pada peralatan, maka akan mencemari susu jagung (Pratama et al., 2017).

SNI 01-3830-1995 tentang susu kedelai menunjukkan batas maksimal jumlah kandungan bakteri yang aman untuk dikonsumsi manusia adalah $2 \times 10^{2}$ koloni/ml. Hasil yang diperoleh pada hari ke-14 yang masih memenuhi standar mutu kandungan bakteri yaitu pada perlakuan A1B2, A2B2, A3B2, A4B2, A1B3, A2B3, A3B3, dan A4B3. Sedangkan pada masa penyimpanan selama 25 hari, hasil yang diperoleh berada di atas standar mutu yang telah ada.

\section{Kesimpulan}

Penelitian yang telah dilakukan menunjukan bahwa semakin meningkatnya kadar CMC dan asam sitrat yang ditambahkan, maka kadar abu, protein dan kadar gula pada susu jagung juga akan meningkat. Sebaliknya pada hasil Analisis kadar lemak, semakin meningkat kadar CMC dan asam sitrat yang ditambahkan, maka semakin rendah kadar lemak yang diperoleh.

Perlakuan optimal diperoleh pada perlakuan 0,3\% CMC dan $0,01 \%$ asam sitrat dengan hasil analisa kadar abu $0,13 \%$, kadar protein 0,54\%, kadar lemak 0,18\%, dan gula total $19,23 \%$. Ketahanan simpan susu jagung yang disimpan pada refrigerator sampai hari ke-25 masih bagus dengan cemaran mikroba (angka lempeng total) yaitu $8,1 \times 10^{3} \mathrm{koloni} / \mathrm{ml}$ dan memenuhi standar SNI 3719: 2014 (minuman sari buah).

\section{Daftar pustaka}

Abdullah, F., Mutia, A.K., 2020. Pengaruh penambahan CMC (Carboxyl Methyl Cellullose) terhadap uji organoleptik otak-otak ikan nike. J. Pendidik. Teknol. Pertan. 6, 171-180.

Adji, I.S., 2010. Pengemasan dan penyimpanan minuman sari jagung. Institut Pertanian Bogor.

Agustina, W., Andriana, Y., 2010. Karakterisasi produk yoghurt susu nabati 1-5.

Barat, B.S., 2019. Badan Pusat Statistik Provinsi Sumatera Barat tahun 2019.

Berlian, Z., Fatiqin, A., Agustina, E., 2016. Penggunaan perasan jeruk nipis dalam menghambat bakteri Eschericia Coli pada bahan pangan. J. Bioilmi 2, 5158.

Dharmawan, H., Rahayuni, T., Lestari, O.A., 2019. Formulasi Carboxy Methyl Cellulose dan santan terhadap sifat fisikokimia dan sensori susu nabati jagung manis. Progr. Stud. Agroteknologi, Jur. Budid. Pertanian, Fak. Pertanian, Univ. Tanjungpura, Pontianak.

Ferdiansyah, M., 2016. Kajian karakteristik karboksimetil selulosa (CMC) dari pelepah kelapa sawit sebagai upaya diversifikasi bahan tambahan pangan yang halal. J. Apl. Teknol. Pangan 5, 136139. https://doi.org/10.17728/jatp.198

Harianja, C.H., Rusmarilin, H., Yusraini, E., 2015. Pembuatan susu jagung dengan pengayaan kacang hijau bergerminasi dan penambahan CMC sebagai penstabil. Rekayasa Pangan dan Pertan.

Hartatik, T.D., Damat, 2017. Pengaruh penambahan penstabil CMC dan Gum Arab terhadap karakteristik cookies fungsional dari pati garut termodifikasi. Agritrop 15, 9-25.

Kamsina, Firdausni, Silfia, 2020. Pemanfaatan katekin ekstrak gambir (Uncaria gambier Roxb) sebagai 
pengawet alami terhadap karakteristik mie basah. J. Litbang Ind. 10, 89-95.

Mailoa, M., Rodiyah, S., Palijama, S., 2017. Pengaruh Konsentrasi Carboxymethyl Celulose terhadap kualitas es krim ubi jalar (Ipomea batatas L.). AGRITEKNO, J. Teknol. Pertan. 6, 45-51. https://doi.org/10.30598/jagritekno.2017.6.2.45

Menteri Kesehatan RI, 1988. Peraturan Menteri Kesehatan Republik Indonesia Nomor: 722/MENKES/PER/IX/88 tentang bahan tambahan makanan.

Muhajir, R., Rahim, A., Hutomo, G.S., 2014. Karakteristik fisik dan kimia susu jagung manis pada berbagai lama perebusan. J. Agrol. 21, 95-103.

Prabandari, W., 2011. Pengaruh penambahan berbagai jenis bahan penstabil terhadap karakteristik fisikokimia dan organoleptik yoghurt jagung. Universitas Sebelas Maret.

Pratama, M.Y., Nainggolan, R.J., Nurminah, M., 2017. Pengaruh perbandingan sari buah belimbing wuluh dan sari buah salak selama penyimpanan terhadap mutu fruit tea. J. Rekayasa Pangan Dan Pertan. 5.

Pratiwi, K.I., Zaini, M.A., 2016. Pengaruh konsentrasi gel buah okra (Abelmoschus esculentus L) terhadap mutu es krim campuran susu sapi dan susu kedelai. Pro Food (Jurnal Ilmu dan Teknol. Pangan) 2, 132139.

Sari, N.A., Sustiyah, A., Legowo, A.M., 2014. Total bahan padat, kadar protein , dan nilai kesukaan keju mozarella dari kombinasi susu kerbau dan susu sapi. J. Apl. Teknol. Pangan 3, 152-156.

Satiarini, B., 2006. Kajian produksi dan profitabilitas Pembuatan susu jagung.
Setiawati, B.B., Puspitojati, E., 2011. Evaluasi mutu yoghurt formulasi susu jagung manis - kedelai. J. Ilmu-Ilmu Pertan. 7, 14-23.

Sumarni, S., Muzakkar, M.Z., Tamrin, 2017. Pengaruh penambahan CMC terhadap karakteristik organoleptik, nilai gizi dan sifat fisik susu ketapang. J. Sains dan Teknol. Pangan 2, 604-614.

Sundari, D., Almasyhuri, Lamid, A., 2015. Pengaruh proses pemasakan terhadap protein. Media Litbangkes 25, 235-242.

Sutini, Jauhari, T., Hilwatullisan, 2020. Sosialisasi pembuatan susu jagung manis (sujanis) di kampung $\mathrm{kb}$ layang-layang dikecamatan ilir barat ii kota palembang. Semin. Nas. Apl. Teknol. Pada Masy. 2, 87-90.

Trissanthi, C.M., Susanto, W.H., 2016. Pengaruh konsentrasi asam sitrat dan lama pemanasan terhadap karakteristik kimia dan organoleptik sirup alangalang (Imperata Cylindrica) 4, 180-189.

Usmiati, S., Abubakar, N., Adieb, A., 2020. Pengaruh penggunaan pengental terhadap karakteristik fisikokimia keju mozarella susu sapi. J. Penelit. Pascapanen Pertan. 17, 59. https://doi.org/10.21082/jpasca.v17n1.2020.59-67

Wardhani, D.H., Maharani, D.C., Prasetyo, E.A., 2015. Kajian pengaruh cara pembuatan susu jagung, rasio dan waktu fermentasi terhadap karakteristik yoghurt jagung manis. Momentum 11, 7-12.

Widiantoko, R.K., 2014. Pembuatan es krim tempe jahe (kajian proporsi bahan dan penstabil terhadap sifat fisik, kimia dan organoleptik). J. Pangan dan Agroindustri 2, 54-66. 